\title{
Some Adaptations to Sea Level Rise in the Coastal City of Limbe, Cameroon
}

\author{
Sunday Shende Kometa ${ }^{1}$, Cornelius Mbifung Lambi ${ }^{2} \&$ Tata Emmanuel Sunjo ${ }^{3}$ \\ ${ }^{1}$ Associate Professor of Geography, Head of Geography Department, University of Bamenda, Cameroon \\ ${ }^{2}$ Professor Emeritus, Department of Geography, University of Buea \\ ${ }^{3}$ Ph.D. Fellow, Department of Geography, University of Buea, Cameroon \\ Correspondence: Sunday Shende Kometa, Associate Professor of Geography, Head of Geography Department, \\ University of Bamenda, Cameroon. E-mail: shendek@hotmail.com; lambimc@yahoo.com; \\ tataemmanuel@ymail.com
}

Received: July 25, 2016

Accepted: August 16, $2016 \quad$ Online Published: December 1, 2016

doi:10.5539/jgg.v8n4p23

URL: http://dx.doi.org/10.5539/jgg.v8n4p23

\begin{abstract}
Abundant scientific evidence at our disposal clearly demonstrates that the world's climates have been changing particularly since the advent of the Industrial Revolution. One of these evidences has been the rise in sea level. While inland cities might be confronted with other evidences and impacts of climate change, adapting to sea level rise remains a daunting task for most coastal cities especially those of developing countries. This paper therefore examines the extent of sea level rise in the Cameroonian coastal city of Limbe and the various indigenous adaptation strategies which are being put in place to combat this sea level rise. Using secondary data relating to sea level rise in tropical coastal areas and primary data relating to the various adaptation options to sea level rise, the study establishes that sea level rise will continue to be a problem to this location if adequate and lasting measures are not put in place. While the city has recorded successes especially in real estate development adaptations, other infrastructural facilities which largely support the tourism sector especially along the city's coast line have remained unsustainable. In the wake of the growing sea level rise, perhaps, it is incumbent on the city's authorities to have a holistic approach in the development and management of its coastal infrastructures in order to combat the sea level rise problem which has become a cruel reality in this active tectonic and mobile region of Cameroon.
\end{abstract}

Keywords: Climate Change, Sea level Rise, Adaptations, Challenges, Successes, Limbe, Cameroon

\section{Introduction}

The recognition of the global warming process and the resulting sea level rise is a well established phenomenon in many coastal areas today. In the wake of the unpleasant effects of sea level rise, it is necessary for man to put in place certain adaptation strategies which can help to mitigate sea level rise. Even though the coast of Limbe (Figure 1) consists dominantly of basaltic rocks, the impact of wave action is significant on the rocky promontories that project into the Atlantic Ocean. The Limbe Coastal Lowlands are small and these are the areas that carry a large chunk of the population which is likely to be more vulnerable in the event of sea level rise. A classical type area of a transient coastline is the Limbe Down Beach Coastal zone. Ever since the Red Cross building was washed into the sea during the 2001 flood and landslide episode in Limbe, it was clear that the reclamation and infilling which we erroneously regarded as coastal stabilisation adaptations were futile. The protective masonry walls which were built with stones and cement without concrete pillars proved ineffective because once the waves broke through an area, they gnawed into the weak in-filled materials through selective abrasion leading to a systematic collapse of portions of the coastline. As if this experience is not enough, new budgets are voted for the same poor coastal rehabilitation process.

Occasional and exceptional high tides push along the bays and estuaries far inland particularly into Motowo or Crab Quarter wetlands. At the same time, there has been a systematic colonisation of these and other proximal coastal wetlands. So the expanding settlements which have been encroaching into the Motowo coastal wetlands are increasingly at risk with the increasing tendency of sea level rise. Several seaside settlements along the West Coast area of Limbe stand at risk of coastal inundation because of their exposure to the open ocean where no 
coastal stabilisation defences are available or even previewed. Moreover, these coastal settlements have been witnessing a rising sea level and salt water intrusion.

Studies on the impacts and adaptations to sea level rise originating from global warming are largely limited. However, there exists abundant scientific evidence at our disposal which show that sea levels across global coastlines and islands have been rising since the beginning of the 21st Century (Church, et al., 2004). It is important to note that the magnitude and timing of sea level changes have always been fluctuating throughout Earth history. Kominz (2001) noted that although these fluctuations provide insight into the tectonic and climatic history of the Earth, they remain difficult to determine with accuracy. Moon, Song, Bromirski and Miller (2013) confirm this when they noted that human-induced and natural trends of sea level are obscured by variability having time scales ranging from seasonal to multidecadal.

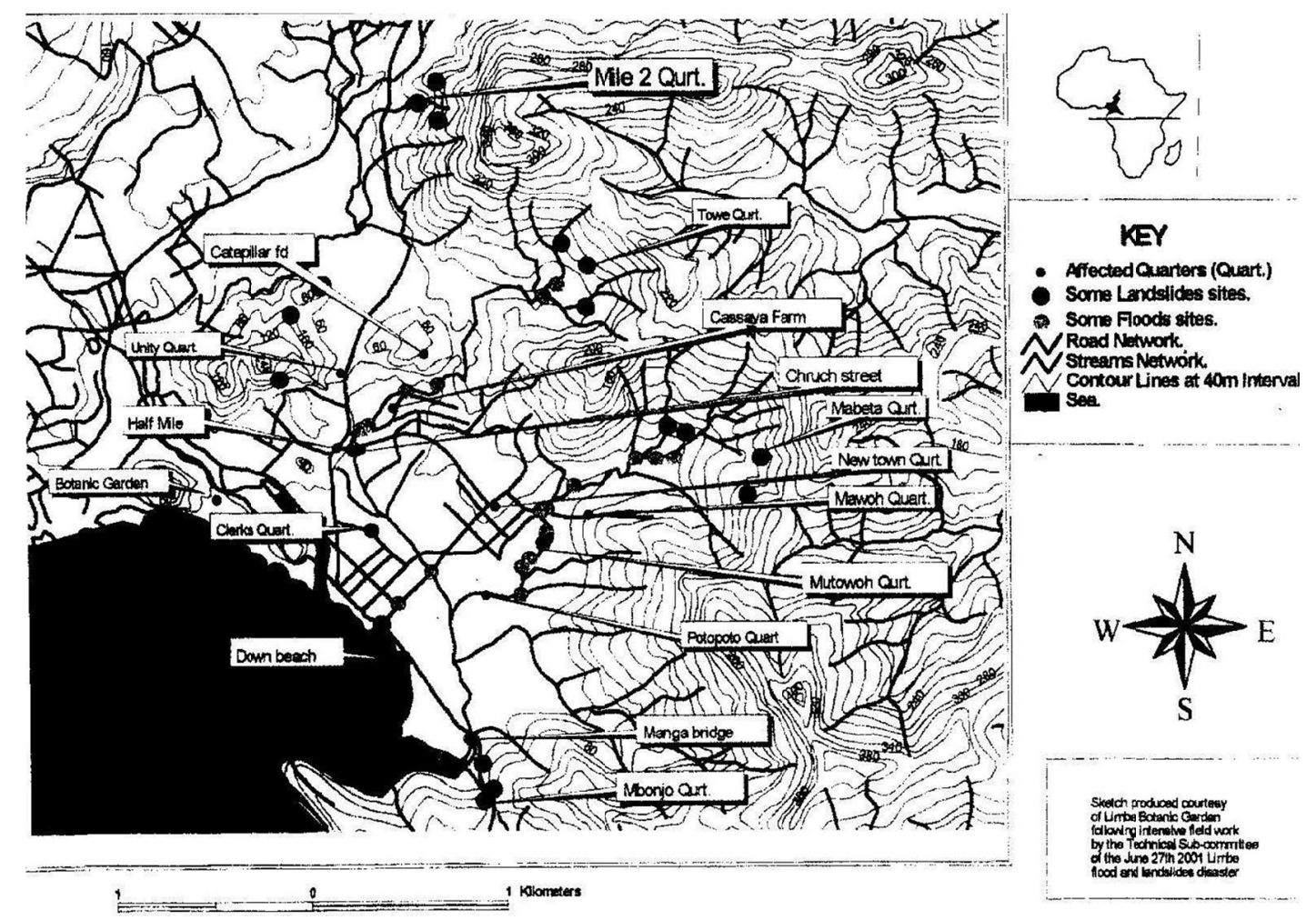

Figure 1. The Delineation of the Limbe High Risk Zones

Source: Lambi et al. 2002.

\section{Research Methods}

This study follows the standard scientific methodology in the social sciences consisting of data collection, data analysis and presentation of findings. The study has, essentially, been based on primary data from field observations, field measurements, and field interviews. Reconnaissance surveys were carried out along the coast of the Limbe Municipality and areas of efficient coastal stabilisation structures along the Idenau stretch of the coast were identified while other weak or vulnerable sites were monitored at the Down Beach area. This is one of the most visited areas by tourists and the city dwellers because of its excellent restaurant facilities and fish barbecue hotspot. Field interviews were carried out with some 25 randomly selected coastal residents on their daily experiences regarding wave actions and tidal inundations associated with sea level rise. The data collected were analyzed descriptively with the results presented in figures and table.

\subsection{Coastal Geology}

The geology and geomorphology of the Limbe Coastline calls for concern in so far as its stability for human settlement and the establishment of urban coastal infrastructures are concerned. This is so because Limbe (Fig 1) is a coastal mobile tectonic city which is prone to seismicity. It lies at the foot of the Mount Cameroon strato volcano. So, lithologically, it is composed of basaltic rocks which are blanketed by scoriaceous deposits having 
been subjected to the strombolian eruptions during which the pyroclastic or scoriaceous deposits were formed. The coastline clearly demonstrates the accumulation of these pyroclastic deposits on the basaltic formations. As these basaltic rocks cooled rapidly in the sub-aerial environment, they are criss-crossed by a network of fractures and joints which form inroads or lines of weaknesses through which wave action impinges on the rock mass causing rapid erosion. The degree of wave dynamics in the process of coastal erosion has been overwhelming, the result of which has been the collapse of some once beautiful sea arches and the rapid deterioration of some man-made coastal structures (Figures 2, 3 \& 4)

The rapid deterioration of the promontories and the collapse of the coastal arches into stacks are all abundant evidence at our disposal that the highly fractured nature of the underlying basalts has been an important contributory factor to coastal denudation in the face of sea level rise. As the consolidated basalts fall prey to rising sea level, the slumping of the unconsolidated scoriaceous deposits is a widespread phenomenon along the cliff around the Kie scoriaceous edifice around the Bota CDC Head Office.

\section{Discussions}

Along this coastal area particularly around Mars Restaurant in the Down Beach coastal area there is a promontory of massive basalts which break and minimise the effects of wave erosion of the man-made coastal structures. This extrusion of massive volcanic rocks and their protective effects teaches us that the coastal stretch from the Ministry of Water and Energy to the Down Beach area could adequately be protected from the constant degradation effects of wave erosion through marine transgression (Figure 2).

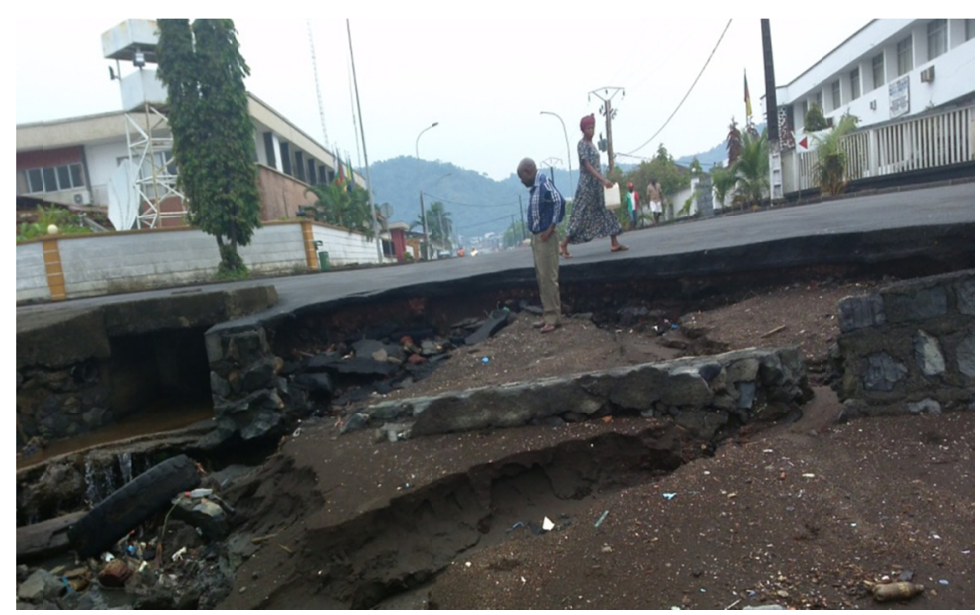

Figure 2. Marine Erosion of the Coastal Highway around BEAC, Down Beach Limbe. Part of the tarred road has collapsed under the impact of the rising sea level

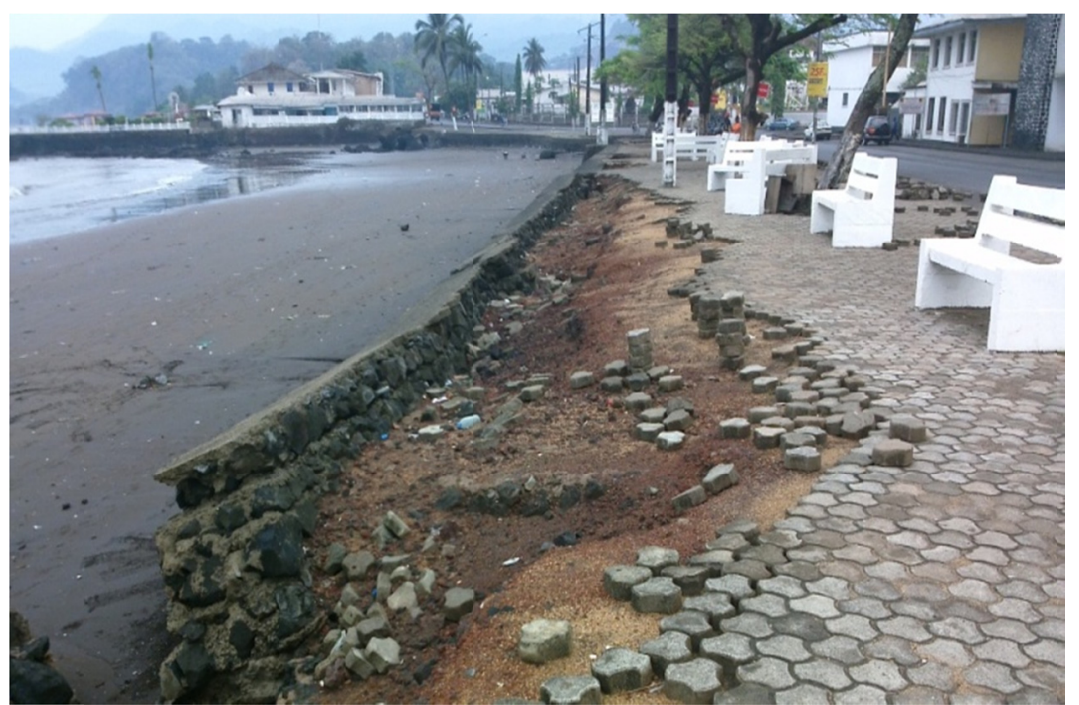

Figure 3. Sea Level Rise and Coastal Erosion of Built-Up Recreational Terraces in Down Beach Coastal Neighbourhood, Limbe 
In much the same way, the Down Beach coastline has often come under periodic marine erosion that provokes the extensive failures and collapse of the built-up coastline (Table 1 \& Fig $3 \&$ 4). Way back in 2001 when Limbe suffered from excessive floods and landslides originating from the Mabeta Hills, sea incursion left an indelible effect of coastal erosion that ate deep into part of the Down Beach road around BEAC Bank (Figure 2) (Ayonghe, et al. 2002).

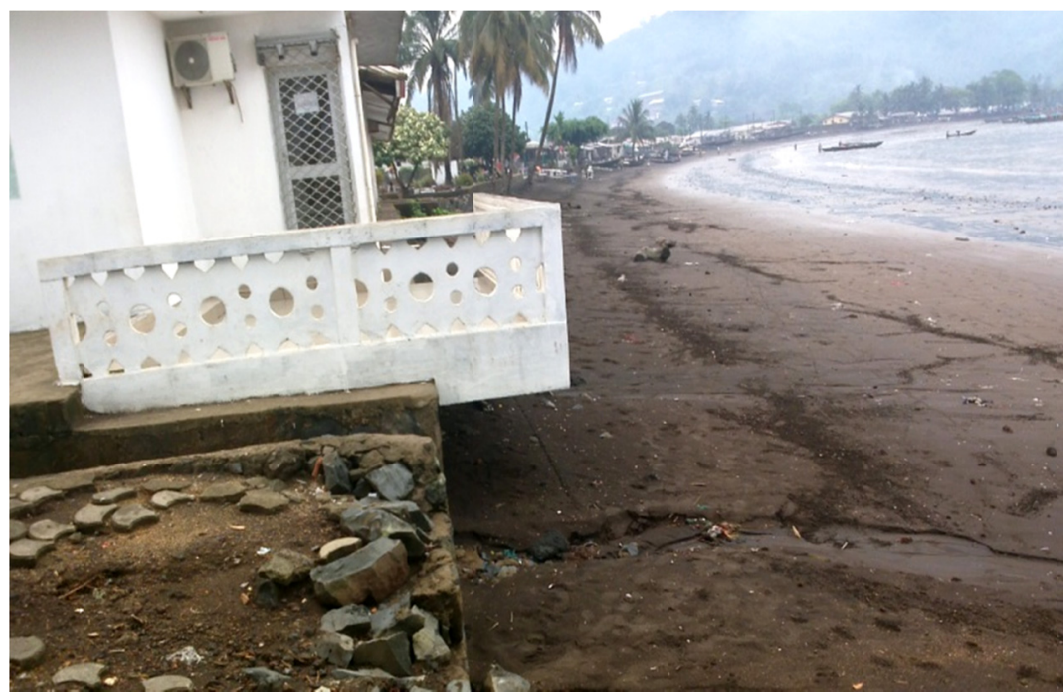

Figure 4. Rising Sea Level and the undermining of built-up structures along the Down Beach Coastline in Limbe

The built-up coastland remains an inadequate strategy in solving the problem of coastal erosion arising from sea level rise. In order to stabilise the coastline along this rapidly degrading zone would require an excavation of the coastline right down to the unweathered bedrock, followed by concreting to prevent the further incursion of waves. These protective structures for now have no concrete reinforcements. All that is done is stone masonry works for aesthetic purposes without the necessary supporting capacity whereas these protective structures should be designed to have reinforced concrete that could stand the test of time.

Table 1. Some Infrastructural Damages Observed along Down Beach, Limbe

\begin{tabular}{cl}
\hline \multicolumn{1}{c}{ Coastal Installations } & \multicolumn{1}{c}{ Some Observations } \\
\hline Inter-urban Road & $\begin{array}{l}\text { Collapse or the breakage of some portions of the tarred } \\
\text { road near BEAC; Need for coastal protection by the use } \\
\text { of concrete caissons. } \\
\text { High Tension Poles }\end{array}$ \\
$\begin{array}{l}\text { Three poles observed to be dangerously poised and are } \\
\text { therefore in transit }\end{array}$ \\
$\begin{array}{l}\text { Coastal recreational } \\
\text { (walks \& pavements) }\end{array}$ & $\begin{array}{l}\text { Severely damaged by the collapse and undercutting by } \\
\text { ferocious sea waves }\end{array}$ \\
Red Cross Building & $\begin{array}{l}\text { Washed into the sea particularly during the June/July } \\
\text { 2001 inundation } \\
\text { Cracks identified in some buildings along the SDOs } \\
\text { Other Buildings } \\
\text { Ondercutting of embankment walls around Mars } \\
\text { Restaurant }\end{array}$ \\
\hline
\end{tabular}

\subsection{Coastal Stabilisation}

Several civilisations have conquered land from the sea for various purposes. In this respect, the world has had a lot to learn from the Dutch in terms of land reclamation from the sea. One quarter of the Netherlands lies below sea level. Another one quarter although slightly above sea level is still low enough to be regularly flooded in the course of natural events. So, more than half of Holland's population live on land that should not, at all, be under their feet. These are the polders which the Dutch have reclaimed from the sea. In spite of these natural handicaps however, the Dutch with their most sophisticated water management expertise have indeed wrestled land from 
the sea. Consequently, the Dutch jokingly say that "God made the world, but the Dutch made the Netherlands" (Kolbert, 2006). These are a people who live with water. Hence, coastal stabilisation is not a new phenomenon. In like manner, we could build extensive bulwarks of coastal defences composed of man-made dykes of concrete caissons with rock boulders or ripraps and dunes dropped at the foot of the caissons for reinforcement. Behind the concrete structures landwards, the aesthetic pavements could then be put in place as their stability is ensured. Such a rock-buttressed dam-like structure has today been used along the West Coast of Cameroon (Figure 5).

With the rising sea level today and its erosive impacts on the coastline and other human infrastructures, it becomes necessary for us to invoke the use of ripraps which have been used with considerable success along some parts of the Limbe coastline where sea incursions were threatening some piece of the Limbe-Idenau Highway which runs along the coastal lowlands very close to the sea.

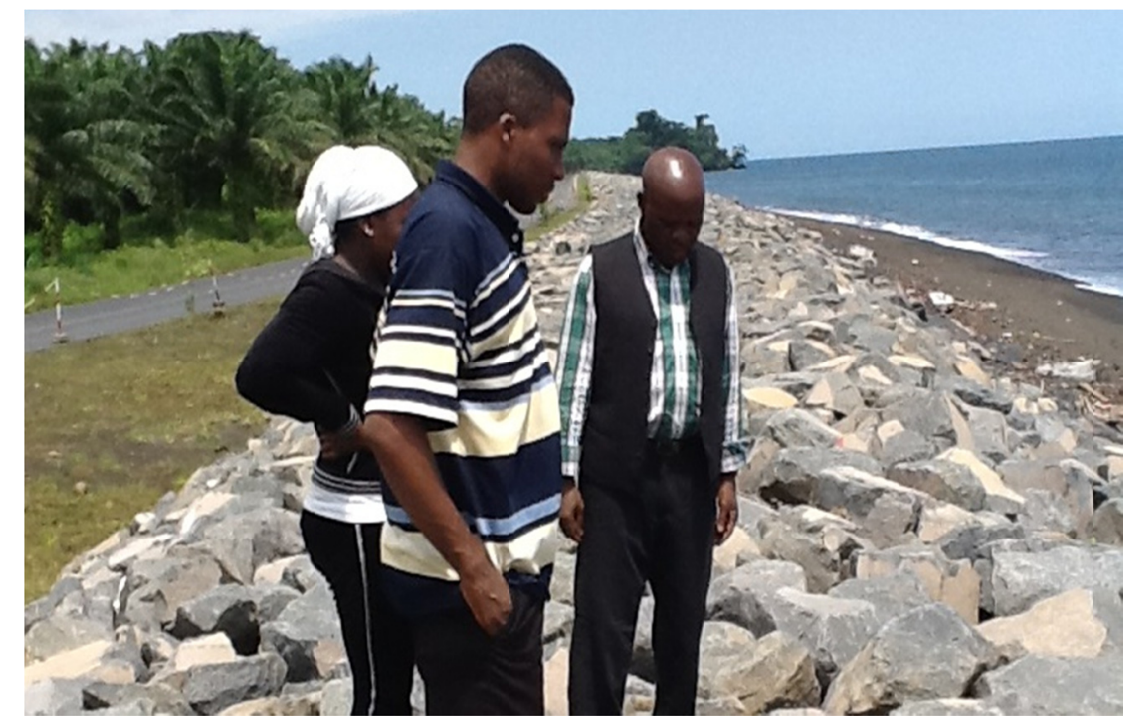

Figure 5. Ripraps which are boulder accumulations have been used along the Limbe Coastline against Coastal Marine Erosion originating from sea level rise

We should learn from successful examples how these polderisation programmes were achieved instead of undertaking the haphazard and unsuccessful and failed attempts on our coastline in the name of a stabilisation process.

During the German colonial period in Cameroon, the coastal area around the Down Beach District Office was rehabilitated using reinforced concrete. All the coastal portions constructed since that time have stood the prolonged wave battery on the coast. The same applies to the Atlantic Beach Hotel and the Botanical Garden which have remained a success story to the present day (Ateba, B., \& Ntepe, N. 1997).

\subsection{Policy Options}

While the love of coastal or sea-side aesthetics has drawn huge waves of the human population to the coast the world over, it should, however, be remembered that rising sea level, property damage and abandonment have also been commonplace scenarios on certain coastlines. Furthermore, many coastal defences fail in the advent of tropical depressions or hurricanes and the occurrence of tsunamis along the mobile coastal zones. In terms of policy options to withstand the rising sea level emanating from the global warming process, it is necessary to locate coastal settlements and infrastructure away from the low-lying areas which are more liable to coastal inundation. For newly built-up structures, cognizance must be taken to ensure that they are well fortified to withstand the impacts of the rising sea level. If in Cameroon we toyed with the issue of sea level rise as if it was nothing to go by even in our life times based on the mistaken believe that sea level rise is slow and largely imperceptible, man's bluff of nature in this respect must now be called off along the Cameroonian coastline because of a number of overwhelming coastal realities which clearly suggest that the global warming process is having a much greater impact today than we suspect. Perhaps, two main Cameroonian examples readily come to mind. The Douala estuarine coastal settlements of Muanko-Youpe have already moved inland as their former 
coastal abodes are now largely inundated by sea waters. Recently, within the coastal region of Limbe, some islanders from the remote Bota Island which has now been very seriously eaten up by wave action arising from the rising sea level have now been resettled on the mainland by the state because of the frightening threats of the rising sea level in what has been christened the Bota Land New Layout. In deed, the rise in the sea level of oceanic waters is much more intense than we have believed it to be in recent history.

\subsection{Coastal Buffers}

Good coastal buffer zones should be created through government policy. Such buffer zones could pass for resting coastal grounds and campsites and recreational grounds which could be evacuated whenever danger from sea level rise is evident. Coastal parks could serve as natural buffers to sea level rise as well as modify the harsh urban climates. With the greenery of such coastal buffers, it helps to add to the aesthetic value of the coastline, and above all, it muffles the effects of the harsh and monotonous urban environment. There is also a need for reclamation. But where these reclamations are made, there should be a proper reclamation process which must be sustainable. Perhaps in recognition of the fact that we cannot fight nature successfully, the coastal municipal authorities must enforce legislation which favour proper reclamation along the coastal wetlands without which they should pass for coastal parks as there is no need for us to experience the same scenario of coastal destruction whenever there are slight weather coastal anomalies. The haphazard reclamation which seems to be a widespread practice only goes to aggravate man's pain and infrastructural destruction during recurrent flood events and probable sea level rise.

\subsection{Resettlement}

In Cameroon, man is attached to his land of birth. But given the realities of the impacts of the magnitude of sea level rise today, it is, perhaps, time for us to part with the doctrinal philosophy that we must live and die in the land of our birth as our seaside settlement locations progressively come under threat from the rising sea water. We are obliged to quit our cherished home; otherwise we should stand up and fight against the rising sea level through the practice of proper reclamation. The alternative, however, is to stay and become nature's environmental refugees when sea level rise and flood magnitudes destitute us from our coastal environments.

\section{Conclusion}

In the midst of growing environmental problems which have been predicated on sea level rise, the need for efficient mitigation measures for the purpose of coastal stabilisation will remain a major preoccupation of the municipal authorities of coastal cities. While we recognise the fact that these proactive measures are not given much premium in many developing countries, it is, however, the best way forward against the threatening impasse of sea level rise.

\section{References}

Ateba, B., \& Ntepe, N. (1997). Post-eruptive Seismic Activity of Mount Cameroon, West Africa: A statistical Analysis. Journal of Volcanology and Geothermal Research, 79, 25-45. http://dx.doi.org/10.1016/S0377-0273(97)00022-X

Ayonghe, S. N., Suh, C. E., Ntasin, E. B., Samalang, P., \& Tantong, W. (2002). Hydrological, Seismically and tectonically triggered landslides along the Cameroon Volcanic Line, Cameroon. Africa Geosciences Review, 9(4), 325-335, France.

Church, J. A., White, N. J., Coleman, R., Lambeck, K., \& Mitrovica, J. K. (2004), Estimates of the regional distribution of sea level rise over the1950-2000 period. J. Clim., 17, 2609-2625

Goudie, A. (1990). The Human Impact on the Environment (3rd ed.). Cambridge: MIT Press.

Kolbert, E. (2006). Field Notes from a Catastrophe: Man, Nature and Climate Change. Bloomsbury, New York: USA. P. $122-132$.

Kometa, S. S. (2012). 'Ensuring Human Safety in the Disaster Prone Coastal Town of Limbe, Cameroon. Journal of Geography and Geology, 4(2). Canadian Center of Science and Education

Kominz, M. A. (2001). Sea Level Variations Over Geologic Time, Western Michigan University, Kalamazoo, MI, USA, Academic Press. http://dx.doi.org/10.1006/rwos.2001r.0255

Lambi, C. M., Kometa, S. S., \& Fombe, L. F. (2002). Environmental Hazards and Landuse Planning for Sustainable Development: The Limbe Unstable Coastal Region, Cameroon. In R.G. Mcinnes \& J. Jakeways, Thomas Tefford (Eds.), Instability, Planning and Management (pp 151-159).

Lambi, C. M., Kometa, S. S., Fogwe, Z. N., \& Apiapuh, G. E. (2001). The May 2000 Enigmatic Volcanic 
Eruption of Mount Cameroon: What Lessons? In Lambi C. M., \& Eze B. E. (2001), Readings in Geography, Unique printers Bamenda (pp 60-68).

Moon, J. H., Song, Y. T., Bromirski, P. D., \& Miller, A. J. (2013). Multidecadal regional sea level shifts in the Pacific over1958-2008, J. Geophys. Res. Oceans, 118. http://dx.doi.org/10.100610.1002/2013JC009297

Reader's Digest (1972). The World around Us. The Reader's Digest Association. P. 224-229.

UNDP Expert Group Meeting, Havana, Cuba, June 19-21.

UNDP. (2002). A Climate Risk Management Approach to Disaster Reduction and Adaptation to Climate Change.

UNISDR (United Nations International Strategy for Disaster Reduction). (2001). Report of Working Group 3 to the ISDR Inter-Agency Task Force for Disaster Reduction, 2001.

United Nations Development Program. (2002). Human Development Report. New York: Oxford University Press.

Winchester, P. (1992). Choice and Vulnersability: A Case Study in Disaster Management in South India. London: James and James Science Publishers.

\section{Copyrights}

Copyright for this article is retained by the author(s), with first publication rights granted to the journal.

This is an open-access article distributed under the terms and conditions of the Creative Commons Attribution license (http://creativecommons.org/licenses/by/4.0/). 